\title{
Complete mitochondrial genome of the Five-dot Sergeant Parathyma sulpitia (Nymphalidae: Limenitidinae) and its phylogenetic implications
}

\author{
TIAN Li-Li ${ }^{1}$, SUN Xiao-Yan ${ }^{2}$, CHEN Mei ${ }^{1}$, GAI Yong-Hua ${ }^{2}$, HAO Jia-Sheng, ${ }^{1,2, *}$, YANG Qun ${ }^{2, *}$ \\ (1. College of Life Sciences, Anhui Normal University, Wuhu 241000, China; 2. LPS, Institute of Geology and Palaeontology, \\ the Chinese Academy of Sciences, Nanjing 210008, China)
}

\begin{abstract}
The complete mitochondrial genome of the Parathyma sulpitia (Lepidoptera, Nymphalidae, Limenitidinae) was determined. The entire mitochondrial DNA (mtDNA) molecule was $15268 \mathrm{bp}$ in size. Its gene content and organization were the same as those of other lepidopteran species, except for the presence of the $121 \mathrm{bp}$ long intergenic spacer between $\operatorname{trnSl}(\mathrm{AGN}$ ) and $\operatorname{trnE}$. The 13 protein-coding genes (PCGs) started with the typical ATN codon, with the exception of the coxl gene that used CGA as its initial codon. In addition, all protein-coding genes terminated at the common stop codon TAA, except the nad4 gene which used a single $\mathrm{T}$ as its terminating codon. All 22 tRNA genes possessed the typical clover leaf secondary structure except for trnSl(AGN), which had a simple loop with the absence of the DHU stem. Excluding the A+T-rich region, the mtDNA genome of $P$. sulpitia harbored 11 intergenic spacers, the longest of which was $121 \mathrm{bp}$ long with the highest $\mathrm{A}+\mathrm{T}$ content (100\%), located between $\operatorname{trnSl(AGN)}$ and $\operatorname{trnE}$. As in other lepidopteran species, there was an 18-bp poly-T stretch at the 3 '-end of the A+T-rich region, and there were a few short microsatellite-like repeat regions without conspicuous macro-repeats in the A+T-rich region. The phylogenetic analyses of the published complete mt genomes from nine Nymphalidae species were conducted using the concatenated sequences of 13 PCGs with maximum likelihood and Bayesian inference methods. The results indicated that Limenitidinae was a sister to the Heliconiinae among the main Nymphalidae lineages in this study, strongly supporting the results of previous molecular data, while contradicting speculations based on morphological characters.
\end{abstract}

Key words: Parathyma sulpitia; Lepidoptera; Nymphalidae; Limenitidinae; Mitochondrial genome

\section{残锷线蛱蝶线粒体基因组全序列及其系统学意义}

\author{
田丽丽 ${ }^{1}$, 孙晓燕 ${ }^{2}$, 陈 梅 ${ }^{1}$, 盖永华 ${ }^{2}$, 郝家胜 ${ }^{1,2, *}$, 杨 群 ${ }^{2, *}$ \\ （1. 安徽师范大学 生命科学学院分子进化与生物多样性研究室，安徽 芜湖 241000; \\ 2. 中国科学院南京地质古生物研究所 现代古生物学与地层学国家重点实验室, 南京 210008)
}

摘要: 对残锷线蛱蝶 (Parathyma sulpitia) (鳞翅目: 蛱蝶科)线粒体基因组全序列进行了测定。结果表明: 残锷线蛱蝶线粒体基因组全序列全长为 $15268 \mathrm{bp}$, 除了在 $\operatorname{trnSl}(\mathrm{AGN})$ 和 $\operatorname{trnE}$ 基因之间有一段 $121 \mathrm{bp}$ 长的基因间 隔外, 其基因的排列顺序及排列方向与大多数已测鳞翅目物种基本一致。在蛋白质编码基因中, 除 cox 1 以 CGA 作 为其起始密码子之外, 其余 12 个蛋白质编码基因都以标准的 ATN 作为起始密码子。此外, 除 nad4 基因以单独的 $\mathrm{T}$ 为终止密码子, 其余 12 个蛋白质编码基因都以 TAA 结尾。除 $\operatorname{trnSl}(\mathrm{AGN}$ ) 缺少 DHU 臂之外, 22 个 tRNA 基因都 显示典型的三叶草形二级结构。除 $\mathrm{A}+\mathrm{T}$ 富集区外的非编码序列中, 线粒体基因组共含有 11 个基因间隔区。其中, 最长的一个 $121 \mathrm{bp}$ 的基因间隔区位于 $\operatorname{trnS} 1(\mathrm{AGN})$ 和 $\operatorname{trnE}$ 之间, 其 $\mathrm{A}+\mathrm{T}$ 含量高达 $100 \%$ 。另外, 和其他鳞翅目物种 一样, 在其 $\mathrm{A}+\mathrm{T}$ 富集区的 3'端有一段长达 $18 \mathrm{bp}$ 的 poly- $\mathrm{T}$ 结构。 $\mathrm{A}+\mathrm{T}$ 富集区内部没有明显的小卫星样多拷贝重复

Received date: 2011-11-18; Accepted date: 2012-02-28

Foundation items: This work was supported by the National Natural Science Foundation of China (41172004), the CAS/SAFEA International Partnership Program for Creative Research Teams, Chinese Academy of Sciences (KZCX22YW2JC104), the Provincial Key Project of the Natural Science Foundation from the Anhui Province, China (KJ2010A142), and the Open Funds from the State Key Laboratory of Palaeobiology and Stratigraphy, Nanjing Institute of Geology and Palaeontology, Chinese Academy of Sciences

*Corresponding authors (通信作者), E-mail: jshaonigpas@sina.com; qunyang@nigpas.ac.cn

收稿日期: 2011-11-18; 接受日期：2012-02-28 
序列, 而含有一些微卫星样的重复结构。本研究基于 13 种蛋白编码基因序列的组合数据, 用最大似然法和贝叶斯 法对蛱蝶科几个主要亚科间共 9 个代表物种间的系统发生关系进行了分析。结果表明, 本研究的结果与前人的分 子系统学研究结论基本吻合(其中, 线蛱蝶亚科和釉蛱蝶亚科互为姐妹群), 而与形态学的研究结论不一致。

关键词: 残锷线蛱蝶; 鳞翅目; 蛱蝶科; 线蛱蝶亚科; 线粒体基因组

中图分类号：Q969.42; Q969.439.2; Q754 文献标志码：A 文章编号：0254-5853-(2012)02-0133-11

Insect mitochondrial DNA (mtDNA) is a circular DNA molecule $14-20 \mathrm{~kb}$ in size with 13 protein-coding genes (PCGs), two ribosomal RNA genes, 22 tRNA genes, and one $\mathrm{A}+\mathrm{T}$-rich region which contains the initiation sites for transcription and replication (Boore, 1999; Clayton, 1992; Wolstenholme, 1992). In recent years, owing to its maternal inheritance, lack of recombination and accelerated nucleotide substitution rates compared to those of the nuclear DNA, the mitochondrial genome has been popularly used in studies on phylogenetics, comparative and evolutionary genomics, population genetics, and molecular evolution.

The Nymphalidae is one of the largest groups of butterflies, comprising about 7200 described species throughout the world. Its systematic and evolutionary process has long been a matter of controversy (Ackery, 1984, 1999; de Jong et al, 1996; Ehrlich, 1958; Harvey, 1991). Until recently, however, only eight complete or nearly complete $\mathrm{mt}$ genome sequences have been determined from Nymphalidae among some forty sequences for Lepidoptera. That is, two from Heliconiinae, two from Satyrinae, and one each from Calinaginae, Apaturinae, Danainae, and Libytheinae.

Limenitidinae is a subfamily of Nymphalidae that includes the admirals and its close relatives. This butterfly group has long been the subject of scientific curiosity, serving as the model organism in diverse fields such as genetics, developmental biology, and evolutionary ecology (Fiedler, 2010; Platt \& Maudsley, 1994). However, its sub-group classifications and phylogenetic relationships with the other Nymphalidae groups remains unresolved based on morphological and molecular criteria (Freitas \& Brown, 2004; Wahlberg et al, 2003, 2005; Wahlberg \& Wheat, 2008; Zhang et al, 2008).

Parathyma sulpitia is a representative species of the subfamily Limenitidinae (Lepidoptera: Nymphalidae) and it is widely distributed in Southeastern Asian areas, such as Vietnam, Burma, India, and China. We determined its complete mitochondrial genome sequence and compared this sequence with those of the other eight-nymphalid butterfly species available. Additionally, we performed phylogenetic analyses using maximum likelihood and Bayesian inference methods based on the concatenated 13 protein coding gene (PCG) sequences. The new sequence data and related analyses may provide useful information about the systematics and evolution of Nymphalidae at the genomic level.

\section{Materials and Methods}

\subsection{Specimen collection}

Adult butterflies of $P$. sulpitia were collected from the Jiulianshan National Nature Reserve, Jiangxi Province, China. The specimens were preserved immediately in $100 \%$ ethanol and then stored at $-20{ }^{\circ} \mathrm{C}$ before genomic DNA extraction.

\subsection{DNA extraction, PCR amplification and sequencing}

Whole genomic DNA was extracted from thoracic muscle tissue with the DNeasy Tissue Kit (Qiagen) after the protocol of Hao et al (2005). Some universal PCR primers for short fragment amplifications of the coxl, $c o b$ and $r r n L$ genes were synthesized (Simon et al, 1994). The remaining short and long primers were designed based on the sequence alignment of the available complete lepidopteran mitogenomes using Primer Premier 5.0 software (Singh et al, 1998).

The entire mitogenome of $P$. sulpitia was amplified in six fragments (cox1-cox3, cox3-nad5, nad5-nad4, nad4-cob, cob-rrnL, rrnL-coxl) using long-PCR techniques with TaKaRa LATaq polymerase under the following cycling conditions: initial denaturation for five minutes at $95{ }^{\circ} \mathrm{C}$, followed by 30 cycles of $95{ }^{\circ} \mathrm{C}$ for $50 \mathrm{~s}$, $45-50{ }^{\circ} \mathrm{C}$ for $50 \mathrm{~s}, 68^{\circ} \mathrm{C}$ for $2 \mathrm{~min}$ and $30 \mathrm{~s}$; and a final extension step of $68{ }^{\circ} \mathrm{C}$ for $10 \mathrm{~min}$. The PCR products were visualized by electrophoresis on $1.2 \%$ agarose gel, then purified using a 3S Spin PCR Product Purification Kit and sequenced directly with an ABI-377 automatic DNA sequencer. For each long PCR product, the full, double-stranded sequence was determined by primer walking. The mitogenome sequence data were deposited into the GenBank database under the accession number JQ347260.

\subsection{Sequence analysis and annotation}

The tRNA genes and their secondary structure were 
predicted using tRNAscan-SE software v.1.21 (Lowe \& Eddy, 1997) and the putative tRNA genes, which were not found by tRNAscan-SE, were determined by sequence comparison of $P$. sulpitia with other lepidopterans. The PCGs and rRNAs were confirmed by sequence comparison with ClustalX1.8 software and NCBI BLAST search function (Altschul et al, 1990). Nucleotide composition and codon usage were calculated with DAMBE software (Xia \& Xie, 2001).

\subsection{Phylogenetic analysis}

Multiple sequence alignments of the concatenated sequences the 13 PCGs of the nine nymphalid species with available mitogenomes (Tab. 2) were conducted using Clustal $\mathrm{X} \quad 1.8$ software and then proofread manually (Thompson et al,1997). The phylogenetic trees were constructed using maximum likelihood (ML) (Abascal et al, 2007) and Bayesian inference (BI) (Yang \& Rannala, 1997) methods with moth species Manduca sexta (Cameron \& Whiting, 2008) (Tab. 2) used as outgroup. The ML analysis for the nucleotide and amino acid sequences were implemented in the PAUP* software (version 4.0b8) (Swofford, 2002) with TBR branch swapping (10 random addition sequences), the best fitting nucleotide substitution model $(\mathrm{GTR}+\mathrm{I}+\Gamma)$ was selected using Modeltest version 3.06 (Posa \& Krandall, 1998), and the confidence values of the ML tree were evaluated via the bootstrap test with 100 iterations. The Bayesian analyses were performed using MrBayes 3.1.2 (Ronquist \& Huelsenbeck, 2003) with the partitioned strategy, the best fitting substitution model was selected as in the ML analysis; the MCMC analyses (with random starting trees) were run with one cold and three heated chains simultaneously for 1000000 generations sampled every 100 generations; Bayesian posterior probabilities were calculated from the sample points after the MCMC algorithm started to converge.

\section{Results}

\subsection{Genome organization}

The mitogenome of $P$. sulpitia was a circular molecule 15268 bp long and consisted of 13 PCGs [cytochrome oxidase subunits 1-3 (cox1-3), NADH dehydrogenase subunits 1-6 and 4L (nad1-6 and nad4L), cytochrome oxidase b (cob), ATP synthase subunits 6 and 8 genes (atp6 and atp8)], two ribosomal RNA genes for small and large subunits ( $r r n S$ and $r r n L), 22$ transfer RNA genes (one for each amino acid and two for leucine and serine) and a non-coding $\mathrm{A}+\mathrm{T}$-rich region. The gene orientation and order of the P. sulpitia mitogenome were identical to those of the other available lepidopteran mitogenomes, except for the presence of the $121 \mathrm{bp}$ long

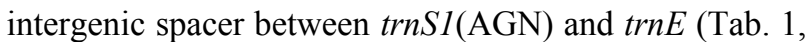
Fig. 1). As is the case in many insect mitogenomes, the major strand coded for more genes (nine PCGs and 14 tRNAs) and the A+T-rich region, whereas less genes were coded in the minor strand (four PCGs, eight tRNAs and two rRNA genes).

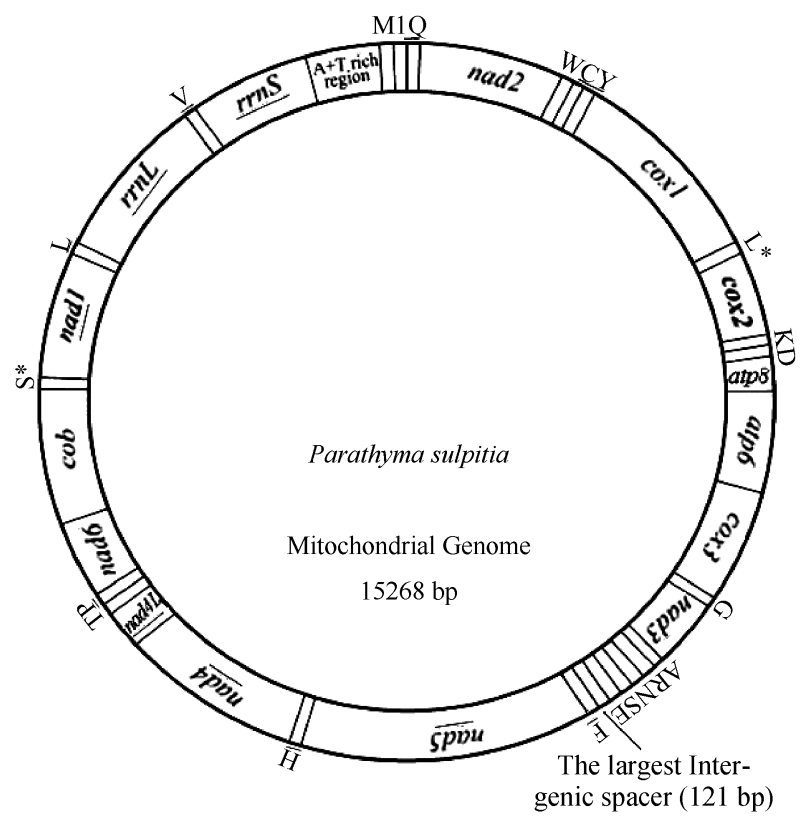

Fig. 1 Circular map of the mitochondrial genome of Parathyma sulpitia

cox1-3: cytochrome oxidase subunit 1-3 genes; atp6, atp 8: ATP synthase subunits 6 and 8 genes; cob: cytochrome oxidase b gene; nadl-6 and nad4L: $\mathrm{NADH}$ dehydrogenase subunits $1-6$ and $4 \mathrm{~L}$. tRNA genes are denoted as one-letter symbol according to the IUPAC-IUB single letter amino acid codes. Gene names that are not underlined indicate the direction of transcription clockwise and with underlines of counter clockwise.

\subsection{Protein-coding genes, tRNA and rRNA genes and A+T-rich region}

All PCGs in the $P$. sulpitia mitogenome were initiated by typical ATN codons (seven with ATG, four with ATT, one with ATA), except the coxl gene which was tentatively designated by the CGA codon (Tab. 1). Twelve PCGs of $P$. sulpitia had a common stop codon (TAA), except for the nad4 gene which harbored a single $\mathrm{T}$.

The 22 tRNAs varied from $61[\operatorname{trn} C$ and

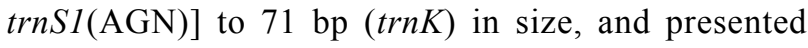
typical clover-leaf structure, with the unique exception of trnS1(AGN), which lacked the dihydrouridine (DHU) 
Tab. 1 Summary of the mitogenome of Parathyma sulpitia

\begin{tabular}{|c|c|c|c|c|c|c|c|}
\hline Gene & Direction & $\begin{array}{c}\text { Nucleotide } \\
\text { number }\end{array}$ & Size & $\begin{array}{c}\text { Intergenic } \\
\text { nucleotides }\end{array}$ & Anti-codon & $\begin{array}{c}\text { Start } \\
\text { codon }\end{array}$ & Stop codon \\
\hline $\operatorname{trn} M$ & $\mathrm{~F}$ & $1-67$ & 67 & 2 & \multirow{3}{*}{$\begin{array}{c}32-34 \text { CAT } \\
\text { 99-101 GAT } \\
168-170 \text { TTG }\end{array}$} & - & \multirow{7}{*}{ TAA } \\
\hline $\operatorname{trnI}$ & $\mathrm{F}$ & $70-134$ & 65 & -3 & & - & \\
\hline $\operatorname{trn} Q$ & $\mathrm{R}$ & $132-200$ & 69 & 52 & & - & \\
\hline $\operatorname{nad} 2$ & $\mathrm{~F}$ & $253-1263$ & 1011 & -2 & \multirow{4}{*}{$\begin{array}{c}- \\
1293-1295 \text { TCA } \\
1350-1352 \text { GCA } \\
1417-1419 \text { GTA }\end{array}$} & ATT & \\
\hline $\operatorname{trn} W$ & $\mathrm{~F}$ & $1262-1328$ & 67 & -8 & & - & \\
\hline $\operatorname{trn} C$ & $\mathrm{R}$ & $1321-1381$ & 61 & 3 & & - & \\
\hline $\operatorname{trn} Y$ & $\mathrm{R}$ & $1385-1450$ & 66 & 4 & & - & \\
\hline $\operatorname{cox} 1$ & $\mathrm{~F}$ & $1455-2990$ & 1536 & -5 & \multirow{2}{*}{$\stackrel{-}{3016-3018 \text { TAA }}$} & CGA & TAA \\
\hline trnL2 (UUR) & $\mathrm{F}$ & $2986-3052$ & 67 & 1 & & - & - \\
\hline $\cos 2$ & $\mathrm{~F}$ & $3054-3767$ & 714 & -35 & \multirow{3}{*}{$\begin{array}{c}- \\
\text { 3763-3765 CTT } \\
\text { 3833-3835 GTC }\end{array}$} & ATG & TAA \\
\hline $\operatorname{trn} K$ & $\mathrm{~F}$ & $3733-3803$ & 71 & -1 & & - & - \\
\hline $\operatorname{trn} D$ & $\mathrm{~F}$ & $3803-3868$ & 66 & 0 & & - & - \\
\hline atp 8 & $\mathrm{~F}$ & $3869-4033$ & 165 & -7 & \multirow{3}{*}{-} & ATT & TAA- \\
\hline atp6 & $\mathrm{F}$ & $4027-4704$ & 678 & 7 & & ATG & TAA \\
\hline $\cos 3$ & $\mathrm{~F}$ & $4712-5500$ & 789 & 2 & & ATG & TAA \\
\hline $\operatorname{trn} G$ & $\mathrm{~F}$ & $5503-5568$ & 66 & 0 & \multirow{2}{*}{ 5533-5535 TCC } & - & - \\
\hline $\operatorname{nad} 3$ & $\mathrm{~F}$ & $5569-5922$ & 354 & 0 & & ATT & TAA \\
\hline $\operatorname{trn} A$ & $\mathrm{~F}$ & $5923-5987$ & 65 & -1 & \multirow{5}{*}{$\begin{array}{c}- \\
\text { 5953-5955 TGC } \\
\text { 6013-6015 TCG } \\
\text { 6079-6081 GTT } \\
6133-6135 \text { GCT }\end{array}$} & - & - \\
\hline $\operatorname{trn} R$ & $\mathrm{~F}$ & $5987-6048$ & 62 & 0 & & - & - \\
\hline $\operatorname{trn} N$ & $\mathrm{~F}$ & $6049-6113$ & 65 & -2 & & - & - \\
\hline $\operatorname{trnS1}(\mathrm{AGN})$ & $\mathrm{F}$ & $6112-6172$ & 61 & 0 & & - & - \\
\hline The largest intergenic & & $6173-6293$ & 121 & 121 & & - & - \\
\hline \multicolumn{8}{|l|}{ spacer } \\
\hline $\operatorname{trn} E$ & $\mathrm{~F}$ & $6294-6358$ & 65 & -2 & \multirow{3}{*}{$\begin{array}{l}\text { 6324-6326 TTC } \\
6388-6390 \text { GAA }\end{array}$} & - & - \\
\hline $\operatorname{trnF}$ & $\mathrm{R}$ & $6357-6422$ & 66 & -20 & & - & - \\
\hline $\operatorname{nad} 5$ & $\mathrm{R}$ & $6403-8154$ & 1752 & 0 & & ATT & TAA \\
\hline $\operatorname{trnH}$ & $\mathrm{R}$ & $8155-8222$ & 68 & 0 & \multirow{2}{*}{$\stackrel{-}{\text { 8188-8190 GTG }}$} & - & - \\
\hline $\operatorname{nad} 4$ & $\mathrm{R}$ & $8223-9561$ & 1339 & -1 & & ATG & T-tRNA \\
\hline $\operatorname{nad} 4 L$ & $\mathrm{R}$ & $9561-9845$ & 285 & 9 & \multirow{4}{*}{$\begin{array}{c}- \\
\text { 9885-9887 TGT } \\
\text { 9952-9954 TGG }\end{array}$} & ATG & TAA \\
\hline $\operatorname{trn} T$ & $\mathrm{~F}$ & 9855-9919 & 65 & 0 & & - & - \\
\hline $\operatorname{trn} P$ & $\mathrm{R}$ & $9920-9983$ & 64 & 11 & & - & - \\
\hline nad6 & $\mathrm{F}$ & $9995-10516$ & 522 & -1 & & ATA & TAA \\
\hline$c o b$ & $\mathrm{~F}$ & $10516-11667$ & 1152 & -2 & \multirow{3}{*}{$\begin{array}{c}- \\
11695-11697 \text { TGA }\end{array}$} & ATG & TAA \\
\hline $\operatorname{trnS2}(\mathrm{UCN})$ & $\mathrm{F}$ & $11666-11730$ & 65 & -2 & & - & - \\
\hline nadl & $\mathrm{R}$ & $11729-12685$ & 957 & 1 & & ATG & TAA \\
\hline $\operatorname{trnL} 1$ (CUN) & $\mathrm{R}$ & $12687-12754$ & 68 & 0 & \multirow{4}{*}{$\begin{array}{c}- \\
12723-12725 \text { TAG } \\
- \\
14108-14110 \text { TAC }\end{array}$} & - & - \\
\hline $\operatorname{rrnL}$ & $\mathrm{R}$ & $12755-14073$ & 1319 & 0 & & - & - \\
\hline $\operatorname{trn} V$ & $\mathrm{R}$ & $14074-14140$ & 67 & 0 & & - & - \\
\hline$r r n S$ & $\mathrm{R}$ & 14141-14919 & 779 & 0 & & - & - \\
\hline $\mathrm{A}+\mathrm{T}$-rich region & $\mathrm{R}$ & $14920-15268$ & 349 & & & - & - \\
\hline
\end{tabular}

stem (Fig. 2). The P. sulpitia tRNAs harbored a total of 24 pair mismatches in their stems, including six pairs in the DHU stems, eight pairs in the amino acid acceptor stems, two pairs in the TYC stems and eight pairs in the anticodon stems, respectively. Among these 24 mismatches, 18 were $G \cdot U$ pairs which formed a weak bond in the secondary structure, and the other six were U.U (Fig. 2).

As with other insect mitogenome sequences, two rRNA genes ( $r r n L$ and $r r n S$ ) were detected in P. sulpitia, located between $\operatorname{trnL} 1$ (CUN) and $\operatorname{trn} V$, and between trn $V$ and $\mathrm{A}+\mathrm{T}$ region, respectively (Fig. 1). The lengths of the $r r n L$ and the $r r n S$ were determined as $1319 \mathrm{bp}$ and $779 \mathrm{bp}$, respectively.

The A+T-rich region of $P$. sulpitia was 349 bp in size. There was an 18-bp poly-T stretch at the $3^{\prime}$ end of the A+T-rich region, and some short microsatellite-like repeat regions without conspicuous macro-repeats throughout the $\mathrm{A}+\mathrm{T}$-rich region.

\subsection{Phylogenetic analysis}

The resultant tree topologies of the ML and Bayesian analyses based on the nucleotide and amino acid sequences were the same, only with a slight difference in their bootstrap support or posterior probability values. For the paper length limit, we have only showed trees based on the nucleotide sequences 

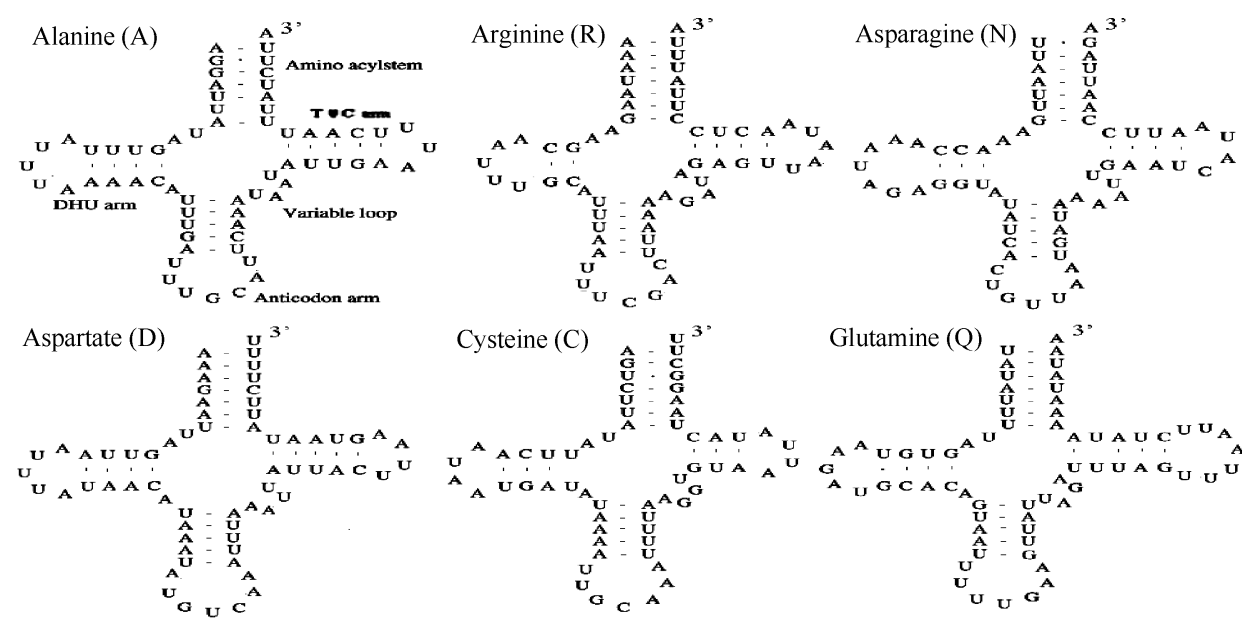

Glutamine (Q)
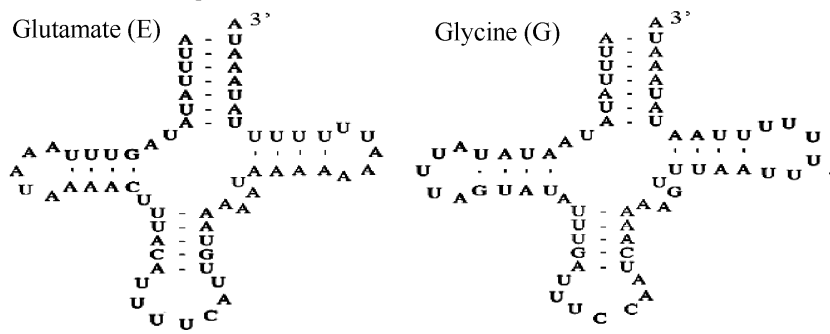

Histidine $(\mathrm{H})$
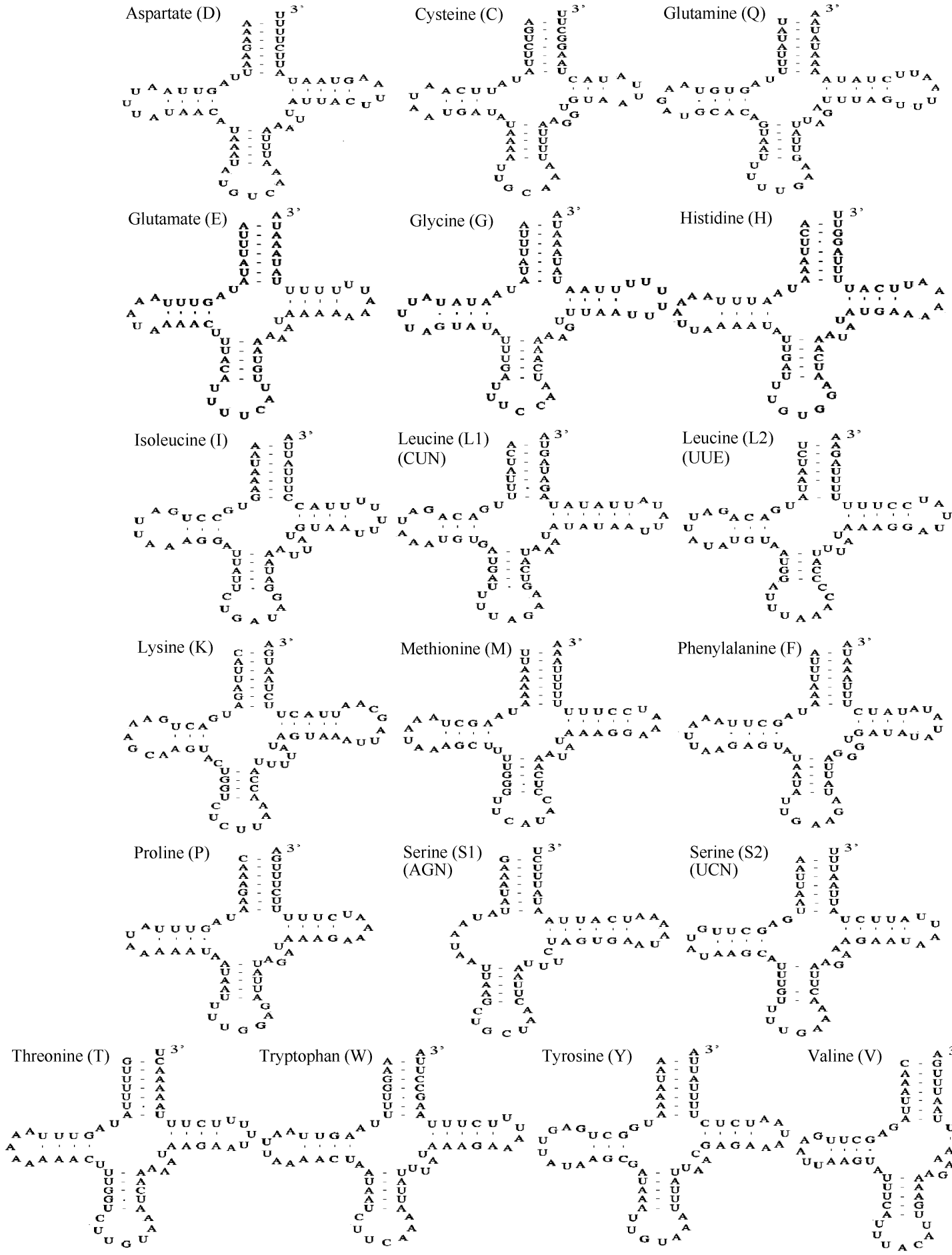

Tyrosine $(\mathrm{Y})$

Fig. 2 Predicted secondary clover leaf structures for the 22 tRNA genes of Parathyma sulpitia

The tRNAs are labeled with the abbreviations of their corresponding amino acids. Nucleotide sequences from 5' to 3' are indicated for tRNAs. Dashes (-) indicate Watson-Crick base-pairing and centered asterisks $(*)$ indicate G.U base-pairing. Arms of tRNAs (clockwise from top) are the amino acid acceptor (AA) arm, T $\psi \mathrm{C}(\mathrm{T})$ arm, the variable loop, the anticodon (AC) arm and the dihydrouridine (DHU) arm. 
(Fig. 4) in this paper.

\section{Discussion}

\subsection{Genome structure, organization and composition}

The $P$. sulpitia mitogenome size $(15268 \mathrm{bp})$ was well within the range detected in the completely sequenced lepidopteran insects, from $15140 \mathrm{bp}$ in
Artogeia melete (GenBank accession no. NC_010568; Hong et al, 2009) to $16094 \mathrm{bp}$ in Agehana maraho (GenBank accession no. NC_014055; Wu et al, 2010). The nucleotide composition of $\mathrm{A}+\mathrm{T}$ for the $P$. sulpitia mitogenome major strand was $81.9 \%$, showing a strongly biased value, which was the highest of all the nymphalid species determined to date (Tab. 2).

Tab. 2 Mitogenomes of the nymphalids used in this study and their partial characteristics

\begin{tabular}{|c|c|c|c|c|c|c|c|c|}
\hline \multirow{2}{*}{ Subfamily } & \multirow{2}{*}{ Species } & \multirow{2}{*}{ Size (bp) } & \multirow{2}{*}{$\mathrm{A}+\mathrm{T}(\%)$} & \multirow{2}{*}{$\begin{array}{l}\text { No. of } \\
\text { codons }\end{array}$} & \multirow{2}{*}{$\begin{array}{c}\mathrm{PCG}^{\mathrm{b}} \\
\mathrm{A}+\mathrm{T}(\%)\end{array}$} & \multicolumn{2}{|c|}{$\mathrm{A}+\mathrm{T}$-rich region } & \multirow{2}{*}{$\begin{array}{l}\text { GenBank } \\
\text { Access no. }\end{array}$} \\
\hline & & & & & & Size (bp) & $\mathrm{A}+\mathrm{T}(\%)$ & \\
\hline Limenitidinae & Parathyma sulpitia & 15268 & 81.9 & 3729 & 80.6 & 349 & 94.6 & This study \\
\hline Calinaginae & Calinaga dauidis & 15267 & 80.4 & 3724 & 78.8 & 389 & 92.0 & HQ658143 \\
\hline Heliconiinae & Acraea issoria & 15245 & 79.7 & 3715 & 78.0 & 430 & 96.0 & NC_013604 \\
\hline Heliconiinae & Argyreus hyperbius & 15156 & 80.8 & 3705 & 79.4 & 349 & 95.4 & JF439070 \\
\hline Apaturinae & Sasakia charonda & 15244 & 79.9 & 3682 & 78.1 & 380 & 91.8 & NC_014224 \\
\hline Libytheinae & Libythea celtis & 15164 & 81.2 & 3709 & 79.9 & 328 & 96.3 & HQ378508 \\
\hline Satyrinae & Melanitis leda & 15122 & 79.8 & 3710 & 78.3 & 317 & 89.6 & JF905446 \\
\hline Satyrinae & Hipparchia autonoe & 15489 & 79.1 & 3709 & 76.8 & 678 & 94.6 & NC_014587 \\
\hline Danainae & Euploea mulciber & 15166 & 81.5 & 3712 & 80.2 & 399 & 93.5 & HQ378507 \\
\hline Sphingidae* & Manduca sexta* & 15516 & 81.8 & 3705 & 80.2 & 324 & 95.4 & NC_ 010266 \\
\hline
\end{tabular}

Total codons were exclusive of the initial and termination codons. * Outgroup.

To evaluate the degree of base bias for the $P$. sulpitia mitogenome, base-skewness was also measured in this study. The results showed that AT and GCskewness values of the whole genome (measured from the major strand) were -0.048 and -0.178 , respectively. This indicated that $\mathrm{T}$ and $\mathrm{C}$ were more frequently used than $A$ and $G$ in the genome, similar to results found in other nymphalid species used in this study (Tab. 3). However, when the two skewness values were considered separately, it was clear that the AT skew was the highest and the GC skew was the lowest of all the nymphalids in this study.

Tab. 3 Nucleotide composition and skewness of the nymphalid mitogenomes

\begin{tabular}{cccccccccccccc}
\hline & \multicolumn{3}{c}{ Major-strand PCGs } & \multicolumn{3}{c}{ Minor-strand PCGs } & \multicolumn{3}{c}{ Whole PCGs } \\
\cline { 2 - 11 } Species & A+T\% & AT skew & GC skew & A+T\% & AT skew & GC skew & A+T\% & AT skew & GC skew & A+T\% & AT skew & GC skew \\
\hline Parathyma sulpitia & 79.2 & -0.172 & -0.100 & 83.1 & -0.154 & 0.266 & 80.6 & -0.164 & 0.026 & 81.9 & -0.048 & -0.178 \\
Hipparchia autonoe & 75.4 & -0.135 & -0.187 & 79.3 & -0.193 & 0.337 & 76.8 & -0.159 & -0.004 & 79.1 & -0.016 & -0.244 \\
Calinaga dauidis & 77.5 & -0.164 & -0.147 & 81.1 & -0.159 & 0.270 & 78.8 & -0.162 & -0.005 & 80.4 & -0.045 & -0.200 \\
Acraea issoria & 76.7 & -0.142 & -0.176 & 80.1 & -0.164 & 0.307 & 78.0 & -0.146 & -0.009 & 79.7 & -0.024 & -0.238 \\
Sasakia charonda & 76.9 & -0.118 & -0.152 & 80.0 & -0.194 & 0.330 & 78.1 & -0.147 & 0.023 & 79.9 & -0.006 & -0.219 \\
Argyreus hyperbius & 77.8 & -0.136 & -0.153 & 82.0 & -0.166 & 0.322 & 79.4 & -0.149 & 0.010 & 80.8 & -0.025 & -0.219 \\
Libythea celtis & 78.8 & -0.124 & -0.094 & 81.8 & -0.174 & 0.297 & 79.9 & -0.144 & 0.040 & 81.2 & -0.017 & -0.181 \\
Melanitis leda & 77.2 & -0.163 & -0.167 & 80.1 & -0.176 & 0.357 & 78.3 & -0.167 & 0.023 & 79.8 & -0.038 & -0.238 \\
Euploea mulciber & 79.0 & -0.142 & -0.124 & 82.1 & -0.140 & 0.307 & 80.2 & -0.140 & 0.020 & 81.5 & -0.038 & -0.211 \\
Manduca sexta* & 79.2 & -0.114 & -0.087 & 82.0 & -0.193 & 0.311 & 80.2 & -0.145 & 0.051 & 81.8 & -0.005 & -0.180 \\
\hline
\end{tabular}

Total codons were exclusive of the initial and termination codons; the skewness of the whole PCGs and the whole genome was calculated from major strand. * Outgroup

\subsection{Protein-coding genes}

Twelve PCGs of $P$. sulpitia mitogenome were initiated by typical ATN codons, except for the coxl gene. For the P. sulpitia COI gene, no typical ATN initiator was found in its starting region or in its neighboring $\operatorname{trn} Y$ sequences. As for the coxl initiation codon in animals, significantly different cases have been reported, for example, tetranucleotides such as TTAG in
Coreana raphaelis (Kim et al, 2006), ATAA in Drosophila yakuba (Clary \& Wolstenholme, 1985) are used, while hexanucleotides such as TATTAG in Ostrinia nubilalis and Ostrinia furnicalis (Coates et al, 2005), TTTTAG in Bombyx mori (Yukuhiro et al, 2002), TATCTA in Penaeus monodon (Wilson et al, 2000), ATTTAA in Anopheles gambiae (Beard et al, 1993), Anopheles quadrimaculatus (Mitchell et al, 1993), and 
Ceratitis capitata (Spanos et al, 2000) are used. Generally, the trinucleotide TTG was assumed to be the coxl start codon for some invertebrate taxa including insect species, such as Pyrocoelia rufa (Bae et al, 2004), Caligula boisdnvalii (Hong et al, 2008), and Acraea issoria ( $\mathrm{Hu}$ et $\mathrm{al}, 2010)$. In this study, however, according to sequence homologies with other available relevant insect species, the codon CGA was hypothesized to be the coxl initiator synapomorphically characteristic of most lepidopteran species (Kim et al, 2009, 2010).

The nad4 gene of $P$. sulpitia harbored a single $\mathrm{T}$, rather than the common stop codon TAA. Incomplete termination codons are frequently observed in most insect mitogenomes including all the sequenced lepidopteran insects to date (Kim et al, 2009), which has been interpreted in terms of post-transcriptional polyadenylation, in which two $\mathrm{A}$ residues are added to create the TAA terminator (Anderson et al, 1981; Ojala et al, 1981).

The value of $\mathrm{A}+\mathrm{T}$ content for all PCGs was $80.6 \%$, whereas, the corresponding values for the major and minor strands were $79.2 \%$ and $83.1 \%$, respectively. Both values were the highest of all the nymphalids analysed in this study (Tab. 4). Furthermore, the A+T content of the PCG third codon position was calculated to be $96.7 \%$, which was significantly higher than those of the first $(74.8 \%)$ and the second $(70.5 \%)$ codon positions. This value was the highest of all the corresponding values among the nymphalids (Tab. 4). With regard to AT-skew, the degree of $\mathrm{A}+\mathrm{T}$ bias was calculated in different strands of the P. sulpitia mitogenome PCGs: the major strand evidenced a value of -0.172 , whereas the minor strand exhibited a value of -0.154 . In contrast, for the GC-skew, the major and minor strands showed values of -0.100 and 0.266 , respectively (Tab. 3). Additionally, the A+T bias of the PCG codon usage for the P. sulpitia mitogenome (the relative synonymous codon frequencies, $\mathrm{RSCU})$ revealed that codons harboring $\mathrm{A}$ or $\mathrm{T}$ in the third position were frequently used compared to other synonymous codons (Tab. 5).

Tab. 4 Summary of base composition at each codon* position of the 13 PCGs in the nymphalid mitogenomes used in this study

\begin{tabular}{|c|c|c|c|c|c|c|c|c|c|c|c|c|c|c|c|c|}
\hline \multirow{2}{*}{ Species } & \multicolumn{4}{|c|}{ 1st codon position } & \multicolumn{4}{|c|}{ 2nd codon position } & \multicolumn{4}{|c|}{ 3rd codon position } & \multicolumn{4}{|c|}{ Overall } \\
\hline & A & $\mathrm{T}$ & $\mathrm{C}$ & $\mathrm{G}$ & A & $\mathrm{T}$ & $\mathrm{C}$ & G & A & $\mathrm{T}$ & $\mathrm{C}$ & $\mathrm{G}$ & A & $\mathrm{T}$ & $\mathrm{C}$ & G \\
\hline Parathyma sulpitia & 36.9 & 37.9 & 9.8 & 15.4 & 22.3 & 48.2 & 16.4 & 13.1 & 42.0 & 54.7 & 2.1 & 1.2 & 33.7 & 46.9 & 9.4 & 9.9 \\
\hline Hipparchia autonoe & 35.9 & 36.3 & 11.3 & 16.4 & 21.5 & 48.4 & 16.4 & 13.7 & 39.7 & 48.8 & 7.1 & 4.4 & 32.3 & 44.5 & 11.6 & 11.5 \\
\hline Calinaga dauidis & 36.3 & 37.7 & 10.4 & 15.7 & 22.2 & 48.4 & 16.4 & 13.1 & 40.7 & 51.5 & 5.1 & 2.7 & 33.0 & 45.8 & 10.6 & 10.5 \\
\hline Acraea issoria & 36.6 & 36.7 & 10.7 & 15.9 & 23.0 & 47.8 & 16.2 & 13.1 & 39.7 & 50.1 & 6.4 & 3.7 & 33.1 & 44.9 & 11.1 & 10.9 \\
\hline Sasakia charonda & 36.7 & 37.6 & 9.8 & 15.9 & 22.3 & 48.3 & 16.1 & 13.3 & 40.9 & 48.5 & 6.1 & 4.4 & 33.3 & 44.8 & 10.7 & 11.2 \\
\hline Argyreus hyperbius & 37.4 & 37.1 & 9.9 & 15.6 & 22.6 & 48.2 & 16.1 & 13.1 & 41.5 & 51.5 & 4.6 & 2.4 & 33.8 & 45.6 & 10.2 & 10.4 \\
\hline Libythea celtis & 36.6 & 37.6 & 9.6 & 16.2 & 22.0 & 48.2 & 16.5 & 13.3 & 44.1 & 51.4 & 2.6 & 1.9 & 34.2 & 45.7 & 9.6 & 10.4 \\
\hline Melanitis leda & 36.0 & 36.9 & 10.8 & 16.3 & 21.9 & 48.3 & 16.2 & 13.6 & 39.8 & 52.0 & 4.9 & 3.3 & 32.6 & 45.7 & 10.6 & 11.1 \\
\hline Euploea mulciber & 37.4 & 37.4 & 9.5 & 15.7 & 21.9 & 48.5 & 16.5 & 13.1 & 44.1 & 51.3 & 3.0 & 1.6 & 34.5 & 45.7 & 9.7 & 10.1 \\
\hline Manduca sexta* & 37.0 & 37.8 & 9.5 & 15.7 & 22.3 & 48.6 & 16.0 & 13.1 & 43.8 & 51.4 & 2.6 & 2.3 & 34.3 & 45.9 & 9.4 & 10.4 \\
\hline
\end{tabular}

* Codons exclusive of the initial and termination codons, * Outgroup.

Tab. 5 Codon usage of the protein coding genes of the Parathyma sulpitia mitogenome

\begin{tabular}{|c|c|c|c|c|c|c|c|}
\hline Codon (Aa) & $\mathrm{n}(\mathrm{RSCU})$ & Codon (Aa) & $\mathrm{n}(\mathrm{RSCU})$ & Codon (Aa) & $\mathrm{n}(\mathrm{RSCU})$ & Codon (Aa) & n (RSCU) \\
\hline UUU (F) & $361.0(1.92)$ & UCU (S) & $132.0(3.12)$ & UAU (Y) & $196.0(1.98)$ & UGU (C) & $31.0(1.94)$ \\
\hline UUC (F) & $16.0(0.08)$ & UCC (S) & $5.0(0.12)$ & $\operatorname{UAC}(\mathrm{Y})$ & $2.0(0.02)$ & $\mathrm{UGC}(\mathrm{C})$ & $1.0(0.06)$ \\
\hline UUA (L) & $485.0(5.29)$ & UCA (S) & $84.0(1.99)$ & $\operatorname{UAA}(*)$ & $0.0(0.00)$ & UGA (W) & $94.0(1.96)$ \\
\hline UUG (L) & $5.0(0.05)$ & UCG (S) & $0.0(0.00)$ & $\operatorname{UAG}(*)$ & $0.0(0.00)$ & UGG (W) & $2.0(0.04)$ \\
\hline CUU (L) & $52.0(0.57)$ & $\mathrm{CCU}(\mathrm{P})$ & $71.0(2.37)$ & $\mathrm{CAU}(\mathrm{H})$ & $63.0(1.85)$ & CGU (R) & $21.0(1.62)$ \\
\hline CUC (L) & $1.0(0.01)$ & $\operatorname{CCC}(\mathrm{P})$ & $11.0(0.37)$ & CAC (H) & $5.0(0.15)$ & CGC (R) & $0.0(0.00)$ \\
\hline CUA (L) & $6.0(0.07)$ & $\mathrm{CCA}(\mathrm{P})$ & $38.0(1.27)$ & CAA (Q) & $64.0(2.00)$ & CGA (R) & $31.0(2.38)$ \\
\hline CUG (L) & $1.0(0.01)$ & CCG (P) & $0.0(0.00)$ & $\mathrm{CAG}(\mathrm{Q})$ & $0.0(0.00)$ & CGG (R) & $0.0(0.00)$ \\
\hline AUU (I) & $474.0(1.95)$ & $\mathrm{ACU}(\mathrm{T})$ & $81.0(2.13)$ & $\operatorname{AAU}(\mathrm{N})$ & $256.0(1.95)$ & AGU (S) & $27.0(0.64)$ \\
\hline $\operatorname{AUC}(\mathrm{I})$ & $12.0(0.05)$ & $\operatorname{ACC}(\mathrm{T})$ & $8.0(0.21)$ & $\operatorname{AAC}(\mathrm{N})$ & $6.0(0.05)$ & $\operatorname{AGC}(\mathrm{S})$ & $2.0(0.05)$ \\
\hline AUA (M) & $250.0(1.95)$ & $\operatorname{ACA}(\mathrm{T})$ & $62.0(1.63)$ & $\operatorname{AAA}(\mathrm{K})$ & $91.0(1.80)$ & $\operatorname{AGA}(\mathrm{S})$ & $88.0(2.08)$ \\
\hline AUG (M) & $7.0(0.05)$ & $\operatorname{ACG}(\mathrm{T})$ & $1.0(0.03)$ & $\operatorname{AAG}(\mathrm{K})$ & $10.0(0.20)$ & $\operatorname{AGG}(\mathrm{S})$ & $0.0(0.00)$ \\
\hline GUU (V) & $67.0(2.14)$ & GCU (A) & $78.0(2.62)$ & GAU (D) & $62.0(1.91)$ & GGU (G) & $66.0(1.38)$ \\
\hline GUC (V) & $1.0(0.03)$ & GCC (A) & $6.0(0.20)$ & GAC (D) & $3.0(0.09)$ & GGC (G) & $1.0(0.02)$ \\
\hline GUA (V) & $57.0(1.82)$ & GCA (A) & $35.0(1.18)$ & GAA (E) & $72.0(1.97)$ & GGA (G) & $107.0(2.24)$ \\
\hline GUG (V) & $0.0(0.00)$ & GCG (A) & $0.0(0.00)$ & GAG (E) & $1.0(0.03)$ & GGG (G) & $17.0(0.36)$ \\
\hline
\end{tabular}




\subsection{Transfer RNA and ribosomal RNA genes}

The P. sulpitia mitogenome harbored 22 tRNA genes, which were scattered throughout its whole region as is typically observed in metazoans including insects (Cha et al, 2007; Crozier \& Crozier, 1993; Hong et al, 2008; Kim et al, 2010; Wilson et al, 2000; Yukuhiro et al, 2002). All tRNAs presented typical clover-leaf structure, with the unique exception of trnSl (AGN), which lacked the dihydrouridine (DHU) stem (Fig. 2). The P. sulpitia tRNAs harbored a total of 22 pair mismatches in their stems, with the number of mismatches in P. sulpitia roughly the same as those detected in other lepidopteran species such as Antheraea pernyi (Liu et al, 2008) and Eriogyna pyretorum (Jiang et al, 2009), but less than those in Ochrogaster lunifer (Salvato et al, 2008). These tRNAs mismatches can be corrected through RNAediting mechanisms, which are well known for arthropod mtDNA (Lavrov et al, 2000).

As in all other insect mitogenome sequences, two rRNA genes ( $r r n L$ and $r r n S)$ were detected in P. sulpitia. They were located between $\operatorname{trnL} 1$ (CUN) and trnV, and between trnV and the $\mathrm{A}+\mathrm{T}$ region, respectively (Fig. 1). The length of the $r r n L$ was determined to be $1319 \mathrm{bp}$, which was within the size range observed in the other available sequenced insects, from $470 \mathrm{bp}$ in Bemisia tabaci (Thao et al, 2004) to 1426 bp in Hyphantria cunea (Liao et al, 2010). The length of the $r r n S$ was determined to be $779 \mathrm{bp}$, which was well within the size range observed in other completely sequenced insects, from $434 \mathrm{bp}$ in Ostrinia nubilalis (Clary \& Wolstenholme, 1985) to $827 \mathrm{bp}$ in Locusta migratoria (Flook et al, 1995).

\subsection{Intergenic spacers and overlapping regions}

The mtDNA genome of $P$. sulpitia included a total of $213 \mathrm{bp}$ intergenic spacer sequences which were spread over 11 regions ranging in size from one to $121 \mathrm{bp}$. The largest spacer sequence (121 bp) was located between the trnS1 (AGN) and the trnE, rather than between the $\operatorname{trn} Q$ and the $n a d 2$ gene as found in other lepidopteran mitogenomes (Tab. 1). This spacer contained the highest $\mathrm{A}+\mathrm{T}$ nucleotide $(100 \%)$ of all the corresponding regions in all other lepidopterans determined. The sequence alignment of this spacer with partial A+T-rich region revealed a sequence homology of $74.4 \%$ (Fig. 3), suggesting that this spacer may have originated from a partial duplication of the A+T-rich region.

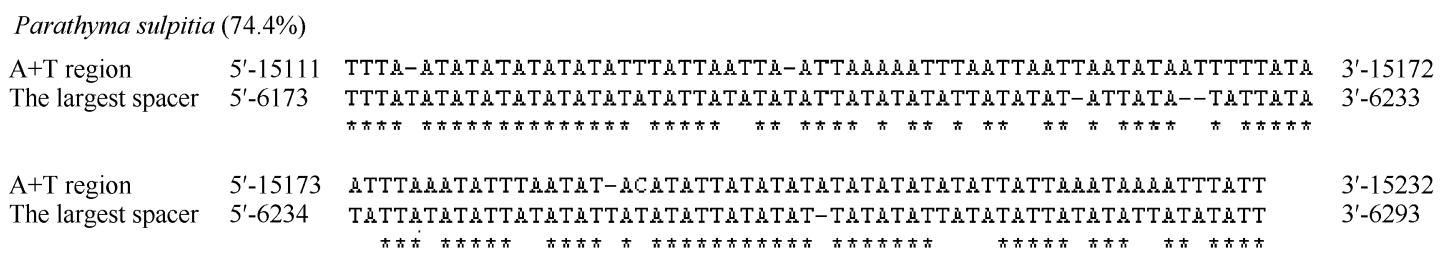

Fig. 3 Alignment of the largest spacer located between $\operatorname{trnS1(AGN)}$ and $\operatorname{trn} E$ and the partial A+T region

The second largest intergenic spacer was 52 bp long, located between the $\operatorname{trn} Q$ and $n a d 2$ genes. This spacer is present in all lepidopteran mitogenomes sequenced, but absent in all non-lepidopteran insects (Hong et al, 2008). The sequence alignment of this spacer with the neighboring nad2 gene revealed a sequence homology of $62 \%$, and thus, this spacer was proposed to have been originated from a partial duplication of the nad2 gene (Kim et al, 2009), with similar cases presented in other sequenced lepidopterans, such as Artogeia melete (70\%) (Hong et al, 2009), C. raphaelis (62\%) (Kim et al, 2006), Parnassius bremeri (70\%) (Kim et al, 2009), and Phthonandria atrilineata (70\%) (Yang et al, 2009). The other nine smaller intergenic spacers ranged in size from one to $11 \mathrm{bp}$ were dispersed throughout the whole genome, and their details are listed in Tab. 1.

A total of $92 \mathrm{bp}$ were identified as overlapping sequences varying from one to $35 \mathrm{bp}$ in 15 regions of the genome (Tab. 2). The longest overlap was $35 \mathrm{bp}$ located between the cox 2 and $\operatorname{trn} K$ genes, and the second largest was $20 \mathrm{bp}$ long located between $\operatorname{trn} F$ and nad5. The third longest was 8 bp between $\operatorname{trn} W$ and $\operatorname{trn} C$, with similarly sized overlaps also detected in other lepidopteran species (Hong et al, 2008). As expected, the $7 \mathrm{bp}$ overlap within the atp 8 and atp 6 reading frames, which is characteristic of many animal mitogenomes (Boore, 1999; Hong et al, 2008), was also detected in this study. In addition, a 5 bp and a 3 bp overlap were located between coxl and trnL (UUR), and between $\operatorname{trn} I$ and $\operatorname{trn} Q$, respectively. As for the remaining nine overlaps of 1 or $2 \mathrm{bp}$ in size, their detailed cases are shown in Tab. 1.

\subsection{A+T-rich region}

The A+T-rich region of $P$. sulpitia was 349 bp in size, located between $r r n S$ and $\operatorname{trn} M$ (Fig. 1). This region showed the second highest A+T content (94.6\%), slightly lower than the largest intergenic spacer (100\%). This region included the $\mathrm{O}_{\mathrm{N}}$ (origin of minority or light strand replication), which was identified by the motif ATAGA 
located $20 \mathrm{bp}$ downstream from $\mathrm{rrnS}$. Additionally, a motif ATAGA followed by 19 bp poly-T, which has been suggested as the structural signal for the recognition of proteins in the replication initiation of minor-strand mtDNA, was detected, which is similar to that observed in other lepidopteran species such as the Bombyx mori (Yukuhiro et al, 2002). Finally, a few of multiple short microsatellite-like repeat regions, such as the $(\mathrm{AT})_{7}$ located 195 bp upstream from $r n n S$ and preceded by the ATTTA motif, were present, which was as expected as they are also detected in the majority of other sequenced lepidopterans (Hong et al, 2008; Hu et al, 2010; Kim et al, 2009; Mao et al, 2010; Pan et al, 2008; Wang et al, 2011; Xia et al, 2011). As for the tRNA-like sequences and the tandemly repeated elements often reported in other lepidopteran species (Kim et al, 2009; Pan et al, 2008), no relevant structures were detected in the $P$. sulpitia A+T-rich region.

\subsection{Phylogenetic analysis}

An up-to-date and comprehensive classification of Nymphalidae was made by Ackery et al (1999) based on morphological characters, while work on molecular systematics of various lineages within Nymphalidae is beginning to clarify their relationships with interesting results (Brower et al, 2000; Wahlberg et al, 2003, 2005). Though the twelve subgroups of Nymphalidae (Libytheinae, Danainae, Charaxinae, Morphinae, Satyrinae, Calinaginae, Heliconiinae, Limenitidinae, Cyrestinae, Biblidinae, Apaturinae, and Nymphalinae) are widely accepted at the subfamily level, some relationships within this group remain unresolved. For example, the phylogenetic positions of Danainae, Libytheinae, and Limenitidinae within Nymphalidae are still controversial.

As for the Limenitidinae, its sister group within the Nymphalidae has been the subject of substantial debate (Freitas \& Brown, 2004; Harvey, 1991). From a morphological view, the close relationships of Limenitidinae, Heliconiinae, Nymphalinae, and Apaturinae have never been suggested (de Jong et al, 1996; Freitas \& Brown, 2004; Harvey, 1991). For example, Freitas \& Brown (2004) conducted a cladistic analysis of Nymphalidae based on immature and adult morphological characters, and the results showed that Limenitidinae is sister to the grouping of (Apaturinae + (Calinaginae + Satyrinae)), exclusive of the remaining nymphalidae taxa (Freitas \& Brown, 2004). However, phylogenetic analyses based on molecular sequence data have convincingly suggested that Limenitidinae is the sister group of Heliconiinae (Brower, 2000; Wahlberg et al, 2003, 2005; Zhang et al, 2008). In this study, the ML and $\mathrm{BI}$ phylogenetic analyses based on the mitogenomic data of the nine available nymphalids, including that of $P$. sulpitia and other unpublished species, revealed the following relationships: (Danainae $+(($ Libytheinae + $(($ Satyrinae + Calinaginae $)+($ Apaturinae + (Heliconiinae + Limenitidinae $)+$ Nymphalinae))) )) with high support values (Fig. 4), which is congruent with those reported by Wahlberg et al $(2003,2005)$ and Brower (2000).

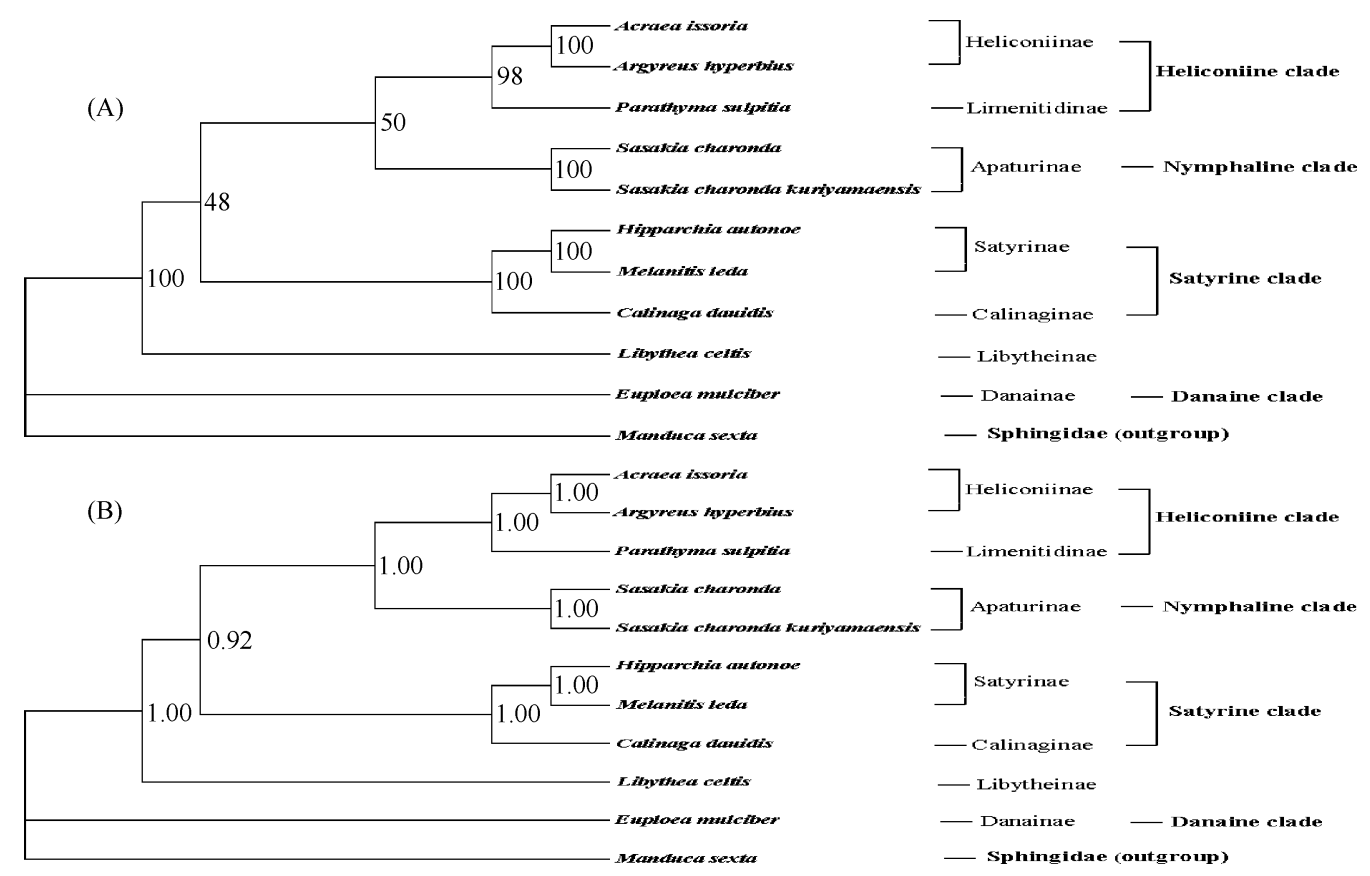

Fig. 4 ML (A) and BI (B) trees of the nymphalid species based on nucleotide sequences of the 13 protein-coding genes Numbers at nodes are bootstrap values/posterior probabilities. 
In conclusion, the complete mitogenome of $P$. sulpitia harbored nearly the same characters as those of other nymphalids. Phylogenetic analysis on a mitogenomic level indicated that Limenitidinae was most closely

\section{References:}

Abascal F, Posada D, Zardoya R. 2007. MtArt: a new model of amino acid replacement for arthropoda[J]. Mol Biol Evol, 24(1): 1-5.

Ackery PR. 1984. Systematic and faunistic studies on butterflies [M] //Vane-Wright RI, Ackery PR. (Eds.), Systematic and Faunistic Studies on Butterflies. Princeton, USA: Princeton University Press, 9-21.

Ackery PR, de Jong R, Vane-Wright RI. 1999. The butterflies: Hedyloidea, Hesperoidea, and Papilionoidea [M] //Kristensen NP. (Ed.), Lepidoptera, Moths and Butterflies. Handbook of Zoology, Lepidoptera. Berlin: De Gruyter, 263-300.

Altschul SF, Gish W, Miller W, Myers EW, Lipman DJ. 1990. Basic local alignment search tool [J]. J Mol Biol, 215(3): 403-410.

Anderson S, Bankier AT, Barrell BG, de Bruijin MHL, Coulson AR, Droujn J, Eperon IC, Nierlich DP, Roe BA, Sanger F, Schreier PH, Smith AJH, Staden R, Young IG. 1981. Sequence and organization of the human mitochondrial genome [J]. Nature, 290(5806): 457465 .

Bae JS, Kim I, Sohn HD, Jin BR. 2004. The mitochondrial genome of the firefly, Pyrocoelia rufa: complete DNA sequence, genome organization, and phylogenetic analysis with other insects [J]. Mol Phylogenet Evol, 32(3): 978-985.

Beard CB, Hamm DM, Collins FH. 1993. The mitochondrial genome of the mosquito Anopheles gambiae: DNA sequence, genome organization, and comparisons with mitochondrial sequences of other insects [J]. Insect Mol Biol, 2(2): 103-124.

Boore JL. 1999. Animal mitochondrial genomes [J]. Nucleic Acids Res, 27(8): 1767-1780

Brower AVZ. 2000. Phylogenetic relationships among the Nymphalidae (Lepidoptera) inferred from partial sequences of the wingless gene [J]. Proc R Soc Lond B, 267(1449): 1201-1211.

Cameron SL, Whiting MF. 2008. The complete mitochondrial genome of the tobacco hornworm, Manduca sexta, (Insecta: Lepidoptera: Sphingidae), and an examination of mitochondrial gene variability within butterflies and moths [J]. Gene, 408(1-2): 112-123.

Cha SY, Yoon HJ, Lee EM, Yoon MH, Hwang JS, Jin BR, Han YS, Kim I. 2007. The complete nucleotide sequence and gene organization of the mitochondrial genome of the bumblebee, Bombus ignitus (Hymenoptera: Apidae) [J]. Gene, 392(1-2): 206220.

Clary DO, Wolstenholme DR. 1985. The mitochondrial DNA molecule of Drosophila yakuba: nucleotide sequence, gene organization, and genetic code [J]. J Mol Evol, 22(3): 252-271.

Clayton DA. 1992. Transcription and replication of animal mitochondrial DNA [J]. Int Rev Cytol, 141: 217-232.

Coates BS, Sumerford DV, Hellmich RL, Lewis LC. 2005. Partial mitochondrial genome sequences of Ostrinia nubilalis and Ostrinia furnicalis [J]. Int J Biol Sci, 1(1): 13-18.

Crozier RH, Crozier YC. 1993. The mitochondrial genome of the honeybee Apis mellifera: complete sequence and genome organization [J]. Genetics, 133(1): 97-117.

de Jong R, Vane-Wright RI, Ackery PR. 1996. The higher classification of butterflies (Lepidoptera): problems and prospects [J]. Entomol Scand, 27(1): 65-101. related to Heliconiinae than other groups of Nymphalidae in this study, strongly supporting the results of former molecular studies, while contradicting the prevailing speculations based on morphological characters.

Ehrlich PR. 1958. The comparative morphology, phylogeny and higher classification of the butterflies (Lepidoptera) [J]. Syst Entomol, 10: 11-32.

Fiedler K. 2010. The coming and going of Batesian mimicry in a Holarctic butterfly clade. BMC Biol, 8(1): 122.

Flook PK, Rowell CHF, Grellissen G. 1995. The sequence organisation, and evolution of the Louocsta migratoria mitochondrial genome[J]. J Mol Evol, 41(6): 928-941.

Freitas AVL, Brown KS Jr. 2004. Phylogeny of the Nymphalidae (Lepidoptera) [J]. Syst Biol, 53(3):363-383.

Hao JS, Li CX, Sun XY, Yang Q. 2005. Phylogeny and divergence time estimation of cheilostome bryozoans based on mitochodrial $16 \mathrm{~S}$ rRNA sequences [J]. Chn Sci Bull, 50(12): 1205-1211.

Harvey DJ. 1991. Higher classification of the Nymphalidae, Appendix B [M] //Nijhout HF. (Ed.), The Development and Evolution of Butterfly Wing Patterns. Washington, DC: Smithsonian Institution Press, 255-273.

Hong GY, Jiang ST, Yu M, Yang Y, Li F, Xue FS, Wei ZJ. 2009. The complete nucleotide sequence of the mitochondrial genome of the cabbage butterfly, Artogeia melete (Lepidoptera: Pieridae) [J]. Acta Biochim Biophys Sin, 41(6): 446-455.

Hong MY, Lee EM, Jo YH, Park HC, Kim SR, Huang JS, Jin BR, Kang PD, Kim KG, Han YS, Kim I. 2008. Complete nucleotide sequence and organization of the mitogenome of the silk moth Caligula boisduvalii (Lepidoptera: Saturniidae) and comparison with other lepidopteran insects [J]. Gene, 413(1-2): 49-57.

Hu J, Zhang DX, Hao JS, Huang DY, Cameron S, Zhu CD. 2010. The complete mitochondrial genome of the yellow coaster, Acraea issoria (Lepidoptera: Nymphalidae: Heliconiinae: Acraeini): sequence, gene organization and a unique tRNA translocation event [J]. Mol Biol Rep, 37(7): 3431-3438.

Jiang ST, Hong GY, Yu M, Li N, Yang Y, Liu YQ, Wei ZJ. 2009. Characterization of the complete mitochondrial genome of the giant silkworm moth, Eriogyna pyretorum (Lepidoptera: Saturniidae) [J]. Int J Biol Sci, 5(4): 351-365.

Kim I, Lee EM, Seol KY, Yun EY, Lee YB, Hwang JS, Jin BR. 2006. The mitochondrial genome of the Korean hairstreak, Coreana raphaelis (Lepidoptera: Lycaenidae) [J]. Insect Mol Biol, 15(2): 217-225.

Kim MI, Beak JY, Kim MJ, Jeong HC, Kim KG, Bae CH, Han YS, Jin BR, Kim I. 2009. Complete nucleotide sequence and organization of the mitogenome of the red-spotted Apollo butterfly, Parnassius bremeri (Lepidoptera: Papilionidae) and comparison with other lepidopteran insects [J]. Mol Cell, 28(4): 347-363.

Kim MJ, Wan XL, Kim KG, Hwang JS, Kim I. 2010. Complete nucleotide sequence and organization of the mitogenome of endangered Eumenis autonoe (Lepidoptera: Nymphalidae) [J]. Afr $J$ Biotechnol, 9(5): 735-754.

Lavrov DV, Brown WM, Boore JL. 2000. A novel type of RNA editing occurs in the mitochondrial tRNAs of the centipede Lithobius forficatus [J]. Proc Natl Acad Sci USA, 97(25): 13738-13742.

Liao F, Wang L, Wu S, Li YP, Zhao L, Huang GM, Niu CJ, Liu YQ, Li MG. 2010. The complete mitochondrial genome of the fall 
webworm, Hyphantria cunea (Lepidoptera: Arctiidae) [J]. Int $J$ Biol Sci, 6(2): 172-186.

Liu Y, Li Y, Pan M, Dai F, Zhu X, Lu C, Xiang Z. 2008. The complete mitochondrial genome of the Chinese oak silkmoth, Antheraea pernyi (Lepidoptera: Saturniidae) [J]. Acta Biochim Biophys Sin, 40(8): 693-703.

Lowe TM, Eddy SR. 1997. tRNAscan-SE: a program for improved detection of transfer RNA genes in genomic sequence [J]. Nucleic Acids Res, 25(5): 955-964.

Mao ZH, Hao JS, Zhu GP, Hu J, Si MM, Zhu CD. 2010. Sequencing and analysis of the complete mitochondrial genome of Pieris rapae Linnaeus (Lepidoptera: Pieridae) [J]. Acta Entomol Sin, 53(11): 1295-1304.

Mitchell SE, Cockburn AF, Seawright JA. 1993. The mitochondrial genome of Anopheles quadrimaculatus species A: complete nucleotide sequence and gene organization [J]. Genome, 36(6): 1058-1073.

Ojala D, Montoya J, Attardi G. 1981. tRNA punctuation model of RNA processing in human mitochondria [J]. Nature, 290(5806): 470474.

Pan MH, Yu QY, Xia YL, Dai FY, Liu YQ, Lu C, Zhang Z, Xiang ZH. 2008. Characterization of mitochondrial genome of Chinese wild mulberry silkworm, Bomyx mandarina (Lepidoptera: Bombycidae) [J]. Sci Chn: Ser C-Life Sci, 51(8): 693-701.

Platt AP, Maudsley JR. 1994. Continued interspecific hybridization between Limenitis (Basilarchia) arthemis astyanax and L. (B.) archippus in the southeastern US (Nymphalidae) [J]. J Lepidopt Soc, 48(3): 190-198.

Posa D, Krandall KA. 1998. Modeltest: testing the model of DNA substitution [J]. Bioinformatics, 14(9): 817-818

Ronquist F, Huelsenbeck JP. 2003. MRBAYES 3: Bayesian phylogenetic inference under mixed models [J]. Bioinformatics, 19(12): 1572-1574.

Salvato P, Simonato M, Battisti A, Negrisolo E. 2008. The complete mitochondrial genome of the bag-shelter moth Ochrogaster lunifer (Lepidoptera, Notodontidae) [J]. BMC Genomics, 9: 331.

Simon C, Frati F, Bekenbach A, Crespi B, Liu H, Flook P. 1994. Evolution, weighting, and phylogenetic utility of mitochondrial gene sequences and a compilation of conserved polymerase chain reaction primers [J]. Ann Entomol Soc Am, 87(6): 651-701.

Singh VK, Mangalam AK, Dwivedi S, Naik S. 1998. Primer premier: Program for design of degenerate primers from a protein sequence [J]. Biotechniques, 24(2): 318-319.

Spanos L, Koutroumbras G, Kotsyfakis M, Louis C. 2000. The mitochondrial genome of the Mediterranean fruit fly, Ceratitis capitata [J]. Insect Mol Biol, 9(2):139-144.

Swofford DL. 2002. PAUP*: Phylogenetic analysis using parsimony (* and other methods), version 4.0 [M]. Sunderland: Sinauer Associates.

Thao ML, Baumann L, Baumann P. 2004. Organization of the mitochondrial genomes of whiteflies, aphids, and psyllids (Hemiptera, Sternorrhyncha) [J]. BMC Evol Biol, 4: 25.

Thompson JD, Gibson TJ, Plewniak F, Jeanmougin F, Higgins DG.
1997. The Clustal X windows interface: Flexible strategies for multiple sequence alignment aided by quality analysis tools $[\mathrm{J}]$. Nucl Acids Res, 25(24): 4876-4882.

Wahlberg N, Braby M F, Brower AVZ, de Jong R, Lee MM, Nylin S, Pierce NF, Sperling FAH, Vila R, Warren AD, Zakharov E. 2005. Synergistic effects of combining morphological and molecular data in resolving the phylogeny of butterflies and skippers $[\mathrm{J}]$. Proc R Soc Lond B, 272(1572): 1577-1586.

Wahlberg N, Weingartner E, Nylin S. 2003. Towards a better understanding of the higher systematics of Nymphalidae (Lepidoptera: Papilionoidea) [J]. Mol Phylogenet Evol, 28(3): 473-484.

Wahlberg N, Wheat CW. 2008. Genomic outposts serve the phylogenomic pioneers: designing novel nuclear markers for genomic DNA extractions of lepidoptera [J]. Syst Biol, 57(2): 231242

Wang XC, Sun XY, Sun QQ, Zhang DX, Hu J, Yang Q, Hao JS. 2011. Complete mitochondrial genome of the laced fritillary Argyreus hyperbius (Lepidoptera: Nymphalidae) [J]. Zool Res, 32(5): 465475.

Wilson K, Cahill V, Ballment E, Benzie J. 2000. The complete sequence of the mitochondrial genome of the crustacean Penaeus monodon: are Malacostracan crustaceans more closely related to insects than to Branchiopods [J]. Mol Biol Evol, 17(6): 863-874.

Wolstenholme DR. 1992. Animal mitochondrial DNA: structure and evolution [J]. Int Rev Cytol, 141: 173-216.

Wu LW, Lees DC, Yen SH, Lu CC, Hsu YF. 2010. The complete mitochondrial genome of the near-threatened swallowtail, Agehana maraho (Lepidoptera: Papilionidae): evaluating sequence variability and suitable markers for conservation genetic studies [J]. Entomol News, 121(3): 267-280.

Xia J, Hu J, Zhu GP, Zhu CD, Hao JS. 2011. Sequencing and analysis of the complete mitochondrial genome of Calinaga davidis Oberthür (Lepidoptera: Nymphalidae) [J]. Acta Entomol Sin, 54(5) 555-565.

Xia X, Xie Z. 2001. DAMBE: Data analysis in molecular biology and evolution [J]. J Hered, 92(4): 371-373.

Yang L, Wei ZJ, Hong GY, Jiang ST, Wen LP. 2009. The complete nucleotide sequence of the mitochondrial genome of Phthonandria atrilineata (Lepidoptera: Geometridae) [J]. Mol Biol Rep, 36(6): 1441-1449.

Yang Z, Rannala B. 1997. Bayesian phylogenetic inference using DNA sequences: A Markov chain Monte Carlo method [J]. Mol Biol Evol, 14(7): 717-724.

Yukuhiro K, Sezutsu H, Itoh M, Shimizu K, Banno Y. 2002. Significant levels of sequence divergence and gene rearrangements have occurred between the mitochondrial genomes of the wild mulberry silkmoth, Bombyx mandarina, and its close relative, the domesticated silkmoth, Bombyx mori [J]. Mol Biol Evol, 19(8): 1385-1389.

Zhang M, Zhong Y, Cao TW, Geng YP, Zhang Y, Jin K, Ren ZM, Zhang R, Guo YP, Ma EB. 2008. Phylogenetic relationship and morphological evolution in the subfamily Limenitidinae (Lepidoptera: Nymphalidae) [J]. Prog Nat Sci, 18(11): 1357-1364. 